\title{
Film Kartografisi: Sinemasal Mekâna Dair Felsefî Düşünceler ${ }^{1}$
}

\author{
Olgu Yiğit*
}

Özet

Film araştırmalarının büyük bölümünü içeren anaakım sinema çalışmaları tarih yazımında da çoğunlukla aynı yaklaşımı benimser ve merkezine de anaakım sinema kuramların alır. Bu kuramlar genellikle ve çoğunlukla filmin özüne bakma derdindedir ve dolayısıyla film materyalinin kendisini ve/veya yönetmenini merkezine almaktadır. Oysa öte yandan, tam da sinemanın kendine içkin özellikleri, ona disiplinler arası bir tutumla yani bütüncül bakmayı zorunlu kılmaktadır. Çünkü tekil olarak farklı anlamlar içeren veya kimi zaman hiçbir anlam taşımayan ögeler, filmin tümel anlatısı içerisinde karşılığın bulmaktadır. Tüm bu ögeleri bir araya getiren, bir bakıma inşa eden kişi olarak yönetmen, film anlatısını yapılandırırken zaman ve hatta mekânı yeniden üretir. Diğer bir deyişle, sinemasal anlatı mekânı, kaynă̆̆ fizikî dünyada mevcut ise bir araya getirerek/kurgulayarak; mevcut değil ise varmış gibi davranarak/inşa ederek üretir. Dolayısıyla yönetmen farkında olarak ya da olmayarak sinemasal coğrafyayı anlatıya zemin teşkil edecek salt bir arka plan değil, onun gü̧̈lü bir ögesi olarak kullanır.

Hem fizikî hem de sinemasal mekânlar, özellikle yönteme dair önermeleri bağlamında anaakım sinema çalışmalarından belirgin bir biçimde ayrnlan Yeni Sinema Tarihi çalışmalarında, son derece özgün bir yöntem olan haritalandırma/kartografi ile araştırılmaya başlanmıştır. Bu çalışmada da, yönetmeni salt auteur yani sadece bir yazar veya ressam olarak gören genel geçer yaklaşımdan ziyade, yönetmeni ayn zamanda bir kartograf olarak gören ve sinemasal anlamın üretiminde ve çözümlenmesinde kartografik yöntemi olanakl kılan sinemasal coğrafya alanındaki yazın derlenecektir. Çalışma kapsamında öncelikle sinema ontolojisini mümkün kılan felsefi bă̆lam açımlanıp ardından sinemasal coğrafya çalışmalarının kuramsal çerçevesi ortaya konacak ve dolayısıyla bu çerçeveyi anlamlı kılan kavramlara bakılacaktır. Dolayısıyla sinemasal kartografiyle bakılan sinemasal anlam, anlatıda kullanılan mekânı felsefi bakış ile yeniden değerlendirme firsatı sunacaktır.

Anahtar Kelimeler: sinemasal mekân, sinemasal coğrafya, sinemasal kartografya, sinema ve mekân, sinemasal mekân ve felsefe

*ORCID: 0000-0002-5572-1951

E-Mail: olguygt@gmail.com

DOI: 10.31122/sinefilozofi.682577

Geliş Tarihi - Recieved: 15.01.2020

Kabul Tarihi - Accepted: 15.05.2020

1 *Bu çalışma, Bilimsel Araştırma Projeleri tarafından desteklenen "Sinemasal Şehri Haritalamak - Yılmaz Güney Filmlerinde Adana" adlı tezin bir parçasıdır. 


\title{
Film Cartography: Philosophizing on The Cinematic Spaces ${ }^{1}$
}

\author{
Olgu Yiğit*
}

\begin{abstract}
The mainstream film cinema studies, including film researches, embrace the same approach also in history writing and have the mainstream cinema theories in their center. These theories mostly are at pains to look into the core of the movie and thus have the film material itself and \or its director in focus. However, on the other hand, the inherent properties of the cinema itself are what make an interdisciplinary and thus holistic look necessary, because elements which have specific different singular meanings or even no meaning at all gains its significance in the comprehensive narrative of the film. The director, who gathers or, in one sense, builds all these elements, creates the scape anew in structuring the narrative of the film. In other words, the cinematic narrative creates the space by fictionalizing it, if its source is in the physical world, or by behaving as if its source exists in the physical world, if not. Thus, consciously or unconsciously, the director uses cinematic geography such that it becomes a part of the narrative, rather than just a background.

In the studies of the New Cinema History, whose claims about the director are substantially different from the ones of the mainstream cinema studies, both physical and cinematic spaces have just begun to be studied with the extraordinarily original method of cartography. Also, in this study, the literature in cinematic cartography, which deems the director not only a mere auteur, writer, or painter as in the mainstream approach, but also a cartographer, and which enables the cartographic method in creating and analyzing the cinematic narrative, will be overviewed. In the scope of the present study, firstly, the philosophical context rendering the ontology of cinema possible will be explained. Secondly, the theoretical framework of the cinematic cartography will be presented, and the terms necessary to understand this framework will be analyzed. Thus, cinematic meaning studied by cinematic cartography opens the way for reevaluating the space in the narrative with a philosophical insight.
\end{abstract}

Keywords: cinematic space, cinematic geography, cinematic cartography, cinema and space, cinematic space and philosophy

\footnotetext{
* ORCID: 0000-0002-5572-1951

E-Mail: olguygt@gmail.com

DOI: 10.31122/sinefilozofi.682577

Received - Geliş Tarihi: 15.01.2020

Accepted - Kabul Tarihi: 15.05.2020
}

1 *Bu çalışma, Bilimsel Araştırma Projeleri tarafından desteklenen "Sinemasal Şehri Haritalamak - Yılmaz Güney Filmlerinde Adana" adlı tezin bir parçasıdır. 


\section{Giriş: Sinema Çalışmaları, Seyir ve Sinemasal Mekânlar}

Sinema çalışmaları, uzunca bir süre kendi özgün kuramı açısından ve tarihselliği üzerinden varlığını sürdürmüştür. Kendi teorisini oluşturması zorunluluğu ile beraber kavramsal olanın sinırlarını çizmesinin ardından, ögesinin ve yaratıcısının insan olması bakımından, disiplinlerarasılığıyla alışıldık kuramlara alternatif yaklaşımlar şekillenmiştir. Anaakım sinema çalışmaları, yönteminin büyük bir bölümünü sinema kuramları üzerinden oluşturur. Dolayısıyla tarihselliği de bu kuramlar çerçevesinde şekillenmiştir. Öncesinde sadece filmlere bakma ve filmi kendi kuramı içerisinde değerlendirme biçiminde olan bu çalışmalar, dönemsel tartışmaların etkisiyle, filmden ve yönetmenden ziyade sinemaya bütüncül bir deneyim olarak bakma/araştırma biçimini dönüştürmüştür. Bu değişimler, sosyal bilimlerin diğer alanlarında da benzer şekilde yaşanmaktadır. Sinema çalışmalarının da sinemanın özsel yapısı gereği bu değişimlerden etkilendiği görülmektedir. Örneğin, bu değişimin sinema alanına sirayet edecek belirtilerinden bazıları Roland Barthes'in (1979) Göstergebilim İlkeleri adlı çalışmasında görülmektedir. Barthes, bu çalışmasında izleyici okumalarının da araştırılması gereken bir mesele olduğu vurgusunu yapar. Çünkü ona göre şeylerin kendi başına, numene benzer gibi birer anlamları yoktur ve izleyici okumaları da bu noktada değişkendir. Diğer bir deyişle izleyicinin konumu o döneme kadar zannedildiği gibi doktrinvari bir konumda değildir. Alanda başlayan bu ve benzeri tartışmaların devamında gerçekleşen önemli bir değişim de David Bordwell ve Kirsten Thompson'un 2011'de yayınlanan Film Sanatı - Bir Giriş adlı çalışmalarıdır. Bordwell ve Thompson, izleyicinin ve yönetmenin konumlarından özne olarak bahsetmesiyle, öznellik ve nesnellik arasındaki değişimlerle kültürel, politik, ırka ve cinsiyete dayalı baskın kültüre ait ögelerin doktrinleşmesi eleştirilmeye başlanmıştır. Diğer bir deyişle, temeldeki değişim sinemanın yönetmen, yapım şirketleri, seyir mekânları, seyircinin kim olduğu, seyircinin öznel ve toplumsal deneyimleri ve daha birçok ögesiyle beraber bütüncül olarak anlamlandırma çabasıdır. Bu noktada sinemasal coğrafya çalışmalarının önemini vurgulamak açısından dikkat çekilmesi gereken şey iki farklı çalışma disiplininin alanları olmasıdır. Öncelikli olarak anaakım sinema çalışmalarının doğal sonucu sinemaya büyük şehirlerin yani metropollerin, sinemasal anlatıdaki yerine ve sinemasal anlatının bir öyküleme biçimi gibi düşünülmesinin sonucu olarak, yönetmenin anlatısında kullandığı öznel diline odaklanılmasıdır, devamında ise Yeni Sinema Tarihi çalışmalarının odağına daha çok seyir deneyimlerini alması olarak görülebilir:

\footnotetext{
"Yeni Sinema Tarihi yaklaşımı, geleneksel/anaakım sinema tarih yazımının film etrafında şekillenen ontolojik ve epistemolojik sorunlarını aşmak amacıyla 2000'ler sonrasında yaygınlaşmıştır. Bu yaklaşım gösterim pratiklerini, kentsel ya da kırsal sinema mekânlarını, sinemaya gitme deneyiminin sosyal ve kültürel tarihini ve seyir pratiğinin kendisini merkezine alan bağlamsal örnekler sunmaktadır. Birbirlerinden çok farklı analitik boyutları olan bu bağlamlar için ise Yeni Sinema Tarihi yaklaşımı, sinema tarihine bakmak için gösterim mekânlarına ve sinemaya gitme deneyimine dair sözlü tarih çalışmalarını; gösterim programları, sinema bültenleri, yerel arşivler gibi birincil kaynakların analizi; iletişim teknolojileri, Coğrafi Bilgi Sistemi (Geographic Information System - GIS) ve veritabanları dolayımıyla analizi mümkün kılacak haritalama ve rotalama gibi geleneksel tarihyazımı
} 
araçlarından çok farklı yeni yeni araştırma yöntemleri önermektedir" (aktaran Çam \& Şanlıer Yüksel, 2019, s. 299).

Kültürel Çalışmalar ve Sinema (2010) kitabında Serpil Kırel, bilgisayar ekranından deneyimlenen bireysel seyirden ziyade, bir ortak yaşam alanında seyirci deneyimlerini konu edinirken, seyircinin uzun bir süre mekân olarak İstanbul'u izlemesinin ardından, Ömer Lütfi Akad sineması ile dışarı çıktığının vurgusunu yapar. Bu bakış açısıyla benzer şekilde Hakan Aydın, Sinemanın Taşrada Gelişim Süreci: Konya'da İlk Sinemalar ve Gösterilen Filmler (1910-1950) (2008), Ali Sait Liman, Gaziantep'te Sinema, Seyir ve Seyirci (1923-1980) (2014), Emine Uçar İlbuğa, 1960-1970'li Yillarda Kent ve Taşra Karşıtlı̆̆ında Türkiye'de Kadınlarm Sinema İzleme Pratikleri Üzerine Bir Araştırma (2017) ve 1960-1970'li Yillarda Antalya'da Sinema İzleme Deneyimi (2018), Aydın Çam, 1960-1975 Yılları arasında Adana'da Filmcilik ve Sinemacılık İşi (2018), Aydın Çam ve İlke Şanlıer Yüksel Sinema Çerçileri - Toros Dă̆ları'nda Sinema Deneyimi (2019), gibi çalışmaları gerçekleştirmiştir. Bu örneklerin genel özellikleri, İstanbul'un dışına çıkarak, merkezin dışında kalan coğrafyalarda hangi filmlerin gösterildiğine, izleyicilerin kimler olduğuna ve sinemasal deneyimin nasıl gerçekleştiğine bakma niyetinde olmalarıdır. Dolayısıyla bu çalışmalar Anadolu'da, taşra kentlerine ve sinema ilişkisine odaklanmaktadır. Uluslararası literatürde de benzer şekilde, büyük kentlerin yerine daha alışılmadık kentlerin sinema kent ilişkisine bakılmaktadır. Diğer taraftan şehir ve sinema bağlamında çalışmalar gerçekleştiren Mehmet Öztürk ise Sine Masal Kentler (2004) adlı kitabında İstanbul, Berlin, Paris, New York gibi büyük metropollerin sinemasal anlatıda kullanılan örneklerini verir. David B. Clarke da Cinematic City (1997) adlı çalışmasında benzer şekilde, Berlin gibi büyük şehirleri ya da popüler filmleri konu edinir. Sinema çalışmalarının yönünün ve kapsamının değişmesi gibi coğrafya çalışmaları alanında da değişiklikler yaşanmıştır. Geleneksel coğrafyanın yani salt fiziksel doğanın bilgisini elde etme çabasında olan bu alanın dışında, beşeri coğrafya ve kültürel coğrafya çalışmaları ortaya çıkmıştır. Geleneksel coğrafyanın çalışma alanları René Descartes'ın, David Hume'un şüpheci yaklaşımından etkilenerek ortaya koyduğu Kartezyen düşünme biçimini içinde barındıran alanlardır; sadece maddî olanı araştırır, insana dair olan soyut düşünme biçimleri ve bu soyut düşünme biçimlerinin sonucu olan üretimlerle coğrafyanın ilişkilenmesine bakmaz.

Şehirlerin değişip büyürken bir organizma gibi kendi içsel doğasına uygun bir biçimde şekil aldığını söyleyebiliriz. Antik Yunan'ın polislerle kurulu düzenine baktığımızda, şehrin en korunması gereken merkezi yapının, dönemine uygun bir biçimde ortada ve en yüksekte bulunan akropolis olduğunu görürüz. Diğer bir deyişle, bakış açısı en geniş olan bu şehir devleti, en yüksek tepededir ve kentin gelişimi onun etrafında şekillenmiştir. Coğrafyalar, toplumsal hayatın merkezlerini belirleyen ittirici gücüyle beraber, akropolis örneğinde gördüğümüz gibi sosyal ilişkilenmelerde de aktif rol oynamaktadır. Bu iki taraflı -insan ve coğrafya- ilişkilenmesi göz önüne alındığında, Antik Yunan kentinin sadece bir tepe üzerine kurulu olması biçiminde yorumlanması anlamsızlaşacaktır ve aksine, bugün hala turizmin odak noktalarından biri olan bu tepe ögesi, insanı içeren alanlarla ilişkili bir biçimde değerlendirilecektir. Bu açılardan, salt maddesel bakan Marksist perspektif, salt dil ve nominallerle açıklayan yapısalcılık ve salt özneden doğru bakan psikolojik bakış açıları da yetersiz kalacaktır. Kültürel coğrafyada, coğrafya ve insan ilişkilerine bakmayı anlamlı 
kılacak bakış açısı Martin Heidegger'inki olacaktır. Heidegger, Edmund Husserl'den alarak eklemlendirmeler yaptığı yöntemi olan hermeneutik fenomenolojiyi ortaya koyar. Dolayısıyla olgusal olanı soyut olandan ayırmadan, bütünsel olarak değerlendiren "insan ve mekân" ilişkisi mümkün olacaktır.

Oysa öte yandan, tam da sinemanın kendine içkin özellikleri, ona disiplinler arası bir tutumla bütüncül bakmayı zorunlu kılmaktadır. Çünkü tekil olarak farklı anlamlar içeren veya kimi zaman hiçbir anlam taşımayan ögeler, filmin tümel anlatısı içerisinde karşılığını bulmaktadır. Tüm bu ögeleri bir araya getiren, bir bakıma inşa eden kişi olarak yönetmen, film anlatısını yapılandırırken zamanı ve hatta mekânı yeniden üretir. Diğer bir deyişle sinemasal anlatı mekânı, kaynağı fizikî dünyada mevcut ise bir araya getirerek/kurgulayarak, mevcut değil ise varmış gibi davranarak/inşa ederek üretir. Yönetmen farkında olarak ya da olmayarak sinemasal coğrafyayı anlatıya zemin teşkil edecek salt bir arka plan değil, onun güçlü bir ögesi olarak kullanır. Sinemasal kent manzaralarının ve şehir coğrafyalarının üretilmesine kaynak sağlaması bakımından, fizikî dünyada varlık bulan şehirler, kültürel coğrafyanın veya daha özelde sinema coğrafyasının önemli bir alanı haline gelmektedir. Buna bağlı olan bir diğer varsayım ise, sinemasal mekânlar her ne kadar yönetmen tarafından inşa edilen/kurgulanan mekânlar olsa ve sinema anlatısının içinde biçim değiştirse, yeni coğrafyalara dönüşse de sinemasal coğrafyaları araştırmak bize kültürel ve fizikî coğrafya araştırmalarının sağladığından çok daha fazla veri sağlar. Çünkü sinemasal mekânlar, fizikî mekânlarla kıyaslanamayacak biçimde zengin bir içerikle yapılandırılmıştır. Açık ya da örtük biçimde fizikî dünyaya dair ekonomik, kültürel, politik ya da toplumsal veriye sinemasal mekânlar aracilığıyla erişebiliriz.

\section{Sinemasal Coğrafyalar ve Film Kartografyası}

Christina Kennedy ve Christopher L. Lukinbeal Towards a Holistic Approach to Geographic Research on Film (1997) adlı makalelerinde, bütüncül bir perspektifle yaklaşılması gereken coğrafi film çalışmalarında, hem yönetmenin hem de seyircinin kendi deneyimleri ve dolayısıyla limitleri olması açısından iki uçlu değişimlerle beraber, filmdeki anlatının yapılandırılacağını söyler. Lefebvre'den yaptığı alıntıda sosyal-bireysel, yerel-küresel gibi iki kutuplu kavramların birbirinin zıttı, birbirini nötrleyen iki ayrı şeyler gibi düşündüğümüzü ancak bunun bir mantıksal bir hata olduğunu ifade ederler. Bu iki uçlu gibi görünen nosyonlar, sinemasal coğrafya alanında da bireysel ve toplumsal olarak iki ayrı odaktan bakılmayı meşru kılar. Ancak, tekrar etmek gerekirse bunlar zıt birer çalışma alanı değildir. Aksine, kendi alanlarını anlamlandıran çalışmaların diğer ucundaki alanın önünü açacağı aşikardır. Sinema çalışmalarında davranışsalcı yaklaşımın ve bilişsel bilimlerin baktığı birey odaklı perspektif, erken dönem Amerikan sinemasal coğrafya çalışmalarında karşımıza çıkar. Bu çalışmalar insan davranışının karmaşık yapısını açıklamaya çalışır. Bu iki uca sosyal çerçeveden bakan taraf ise filmi üreten ekibi ve izleyiciyi karmaşık birer sistem olarak görür ve onların arasındaki dinamik simbiyotik ilişkinin sonucu olan sosyal yapıya odaklanir.

Amy Lynn Corbin Cinematic Geographies (2015), adlı çalışmasında filmin anlatısında tercih edilen fizikî mekânların, belli bir seyircinin bakışı (gaze) dikkate alınarak belirlendiğini 
vurgular. Bu durumda yönetmen sadece anlamsal imgeleri bir araya getiren bir yazar olmaktan çıkar. Yönetmen, aynı zamanda üç boyutlu bir evrenin hayalini serimleyerek, kendi kurgusu olan yeni coğrafyalara bir seyahat düzenlemektedir. Corbin, devaminda Heidegger'in fenomenolojik bakış açısıyla temellendirdiği ünlü makalesini, Building Dwelling Thinking'i (1971), hatırlatarak mekânın ve coğrafyanın, seyredenler için mesken olmaktan çıkıp, bazı anlamlar kazanarak tanıdık duygularla ev (yuva) anlamını da taşıyabileceğini açıklar. Bu tanıdık duyguların dolayımsal olduğunu vurgular. Seyir deneyiminin kendisi de birinci elden deneyimlenmez. Yani yine dolayımsaldır ancak Heidegger'in kendi çalışmasında açıkladığı gibi bir turist bakış açısına benzer de değildir. Dolayımsal olmasına rağmen aynı zamanda izleyici açısından kendi bakış açısıyla gerçekleştiğinden, içsel bir deneyimdir.

Benzer şekilde Christopher L. Lukinbeal ve Stefan Zimmerman Film Geography: A New Subfield (2006) adlı çalışmalarında John K. Wright'in Terrae Incognitae: The Place of the Imagination in Geography (1947) adlı makalesinden aktararak coğrafyanın, nesnel alanlarının yani geleneksel, merkezi araştırmalarının yanında jeosofi (geosophy) olarak adlandırdığı periferik (çevresel) alanların da beraber çalışılmasını önerir. Daha öznel deneyime bağlı olan bu alanlar, keşfedilmemiş yerleri haritalandırma ve anlamlandırma şansı verebilir demektedir. Wright, hatta estetik jeosofi adını verdiği bir alt kategori daha önerir ve bu alanın da edebiyat ve sanat gibi tamamıla öznel perspektife dayalı alanlarla beraber çalışmanın yolunu açacağını söyler. Lukinbeal ve Zimmerman, çalışmalarında aynı zamanda sinemasal coğrafya alanının üç temel alanda incelenmesi gerektiğini vurgular: Jeopolitika, kültürel politika ve küreselleşme. Bu üç kavramla ilişkisini sinematografik açıdan pek de değerli bulmadıkları The Day After Tomorrow (Yarından Sonra, 2004) filmiyle açıklamanın son derece iyi bir örnek olduğunu vurgularlar. Dahası yine sinemasal coğrafya alanı için son derece önemli bir çalışma olan Fredric Jameson'un 1992'de yayınlanan The Geopolitical Aesthetic adlı kitabıyla ilişkilendirirler. Bu çalışmasında Jameson, bilişsel haritalamanın jeopolitik tahayyül için kullanılabileceğini söyler ve devamında tekelci kapitalizm içine ne kadar sürüklenirse bireyin dünyaya dair fenomenolojik tanımlarının sosyal gerçeklik içinde bir o kadar sabitleneceğini vurgular. Devamında bireyin günlük yaşam deneyimlerinin, total kapitalist yapı içerisinde son derece önemsiz olduğunu ve artık sosyal gerçekliği açıklayabilir bir konumda olmadığını söyler. Bu gerçekliğin algı alanında asla tam olarak tezahür etmeyeceğini ve hatta aksine bizim onları tekrar edilebilir teknolojiler içerisinde bulunan sembolik kalıntılar arasında bulabileceğimizi söyler. Film, video ve televizyonun görsel medya aracılığıla bize sunduğu muazzam jeopolitik mekân veya uzamın dejenere görüntüleri, Jameson'a göre bilişsel olarak haritalandırılabilir. Jameson daha önceleri Kevin Lynch'in bilişsel haritalamanın şehir manzaralarını tanımladığı ve meşru kıldığı önermesini hatırlatarak, bireyin sosyal haritalamada kullandığı jeopolitik tahayyül gücünün yeterli olmadığını öne sürer. Lukinbeal, çalışmasının devamında Bunnell'in Re-viewing The Entrapment Controversy: Megaprojection, (Mis)representation and Postcolonial Performance (2004) adlı makalesiyle ilişkilendirerek Jameson'un bilişsel haritalama hakkındaki görüşlerinin özü ile bağ kurar ve filmlerin sadece eğlenmekten çok daha fazlası olduğunu söyler. Dahası filmler ticaret, kültürel anlam ve politika arasındaki ilişkileri açıklayan bir konumdadır. Bu durum için verdiği örnek ise kapitalizmin 1970'lerde küresel durgunluk döneminde 
ekonomik yeniden yapılandırma arayışındayken ticaret, ticaret istihdamı ve en önemlisi kültürler üzerinde çok etkili olduğudur. Lukinbeal, bu durumun sinema sektöründe küreselleşen üretimle beraber ulusaşırı şirketlerin daha ucuza çok daha fazla film üretimi yaptığını söylemektedir. $\mathrm{Bu}$ açıdan bakıldığında, sinema tarihinin alışıldık araştırma alanlarının dışında ve sinemasal anlatıda son derece önemli olan büyük metropoller haricinde de henüz çalışılmamış sinemasal coğrafyalar olduğunu görürüz.

Lukinbeal, Cinematic Landscapes (2005) adlı çalışmasında sinemasal manzaraların ontolojik olarak neye karşılık geldiğini açıklamaya çalışır. Öncelikle 1979' da yayınlanan J. B. Jackson'un Landscape as Theater adlı çalışmasına referansla, manzaranın tiyatro sahnesiyle benzerliğini dile getirerek, tiyatro sahnesinin kullanımının sosyal ve sanatsal belirlenmiş bir takım kurallar çerçevesinde şekillenmesi, insanın tiyatro sahnesini tıpkı manzara gibi kontrol ve dizayn etmesi ve son olarak insanın kendisini sahnenin merkezini işgal etmesi açısından ilişkilendirir. Lukinbeal, Jackson'un çalışmasının sinemasal manzara tartışmalarına anlamlı bir başlangıç noktası oluşturduğunu söyleyerek mekân (space) olarak manzara, yer (place) olarak manzara, temaşa (spectacle) olarak manzara ve metafor olarak manzara biçiminde dört başlıkta tiyatro analojisiyle yaklaştığı ilişkileri açıklamaktadır. Mekân olarak manzara, filmin dramasının ortaya çıkacağı bir alan sağlamaktadır ve bu sebepten sürekli bir eylem alanına dönüşmektedir. Diğer bir deyişle, sosyal mekân sinemasal anlatının ortaya çıkmasına izin veren bir imkân sağlamaktadır ve bu bağlamda mizansen (mise-en-scene), mekân-yer geriliminin ve dinamiklerinin meydana geldiği alan olması açısından önem kazanmaktadır. Lukinbeal, yer olarak manzara için "hayali olsun veya olmasın, belirli bir yeri ve zamanı duyumsatması açısından anlatımı gerçekçi kılmaktadır," der. Bernard Nietschmann'e (1993) referansla bir filmde, güçlü bir mekânın duyumsanmasının dört yolu olduğunu ileri sürer. Öncelikle sinemasal anlatı, üretim boyunca izleyicinin belirli coğrafik ölçekleri anlayacağı şekilde aktarılmaktadır ve bu sebeple izleyici, anlatı esnasında yerinden edilmemektedir veya kaybolmamaktadır. İkincisi, klişe olandan ziyade birden çok imleyeni olan bir yeri mekân olarak kullanan filmler, mekânın günlük karmaşıklıklarının izleyiciye geçmesine izin vermektedir. Üçüncüsü filmler, manzaraları yalnızca birer arka plan olarak değil ve ön planda birer yardımcı oyuncu olarak kullanabilmektedir. Son olarak da anlatı kendi başına (tekil/tikel) eylemlere veya olaylara değil tümel anlatıya bakılarak anlamlandırılmaktadır. Lukinbeal'in bu açılamaya verdiği örnekler ise Walter Salles, Robert Redford, Clint Eastwood, Steven Soderbergh, Woody Allen ve John Sayles gibi yönetmenlerin filmleridir ve Lukinbeal bu yönetmenlerin sinemalarında yer olarak kullanılan manzaraların sosyal mekâna etki ettiği anlatıları için, filmlerinde birer ana bileşen haline geldiği vurgusunu yapmaktadır. Temaşa olarak manzara başlıklı bölümdeyse bazen de manzaraların sadece hoş bir görsellik yaratmak için de kullanılabileceğini hatırlatır. Ancak Lukinbeal, elbette bu noktada temaşa olarak manzaranın bir görüntüde birden çok işlevi birleştirdiğini söyler ve Laura Mulvey'in Görsel Haz ve Anlatı Sineması adlı çok bilinen çalışmasını hatırlatır. Temaşa olarak manzaranın bakış (gaze) içindeki güç ilişkilerini kodladığını söyler. Bu kodların, güzelliği neyin oluşturduğunu, kime baktığını ve nelere baktığını bilmenin sinemasal manzaraların içine yerleştirilmiş doğal güç ilişkilerini ortaya çıkartan ve hatta yeniden üreten bir etkisi olduğunu söylemektedir. Son bölümde ise, metafor olarak kullanılan manzaraların kültürel ve davranışsal özellikleri hakkında belirli yerlerle ilişki kurduklarını 
ve dolayısıyla stereotipleşen yerlerin de sinemasal anlatıda metaforlaşarak kültürel bağlamların anlamlandırılmasını irdelemektedir.

Anton Escher'in, The Geography of Cinema - A Cinematic World (2006) adlı makalesinde bahsettiği gibi ilk olarak Eugen Wirth (1952), Antik Yunan tiyatrosundaki mekânların dramaturjik işleviyle sinemasal manzaranın görüntüyü çerçevelemesi arasında analojik bir ilişki kurmakta ve bunu tiyatro sahnesi metaforuyla açılamaktadır. Buna ek olarak, tiyatro sahnesi metaforuyla ilişkilendirerek, sinemasal manzaranın tıpkı tiyatro sahnesindeki gibi yerleştirilmiş bir düzen içerisinde olduğunu da belirtir. Yani sinemasal manzaralar sadece birer arka plan değildir, kamera açılarıyla da manipüle edilebilmektedirler. Bu bağlamda, sinemasal anlatıda var olan sinemasal manzara, fizikî dünyada karşılığı olsun veya olmasın mekânsal olanın yeniden üretebilmesini mümkün kılmasıyla anlam kazanır. Dahası, sinemasal mekânın kendine özgü deneyimleniş biçimi, fiziksel olandan ayrılır ve mekânın duyumsanmasını (sense of place) yaratarak bu özgün deneyimi meşru kılmış olur.

Lukinbeal, GeoJournal'da yayinlanan The Map That Precedes the Territory: An Introduction to Essays in Cinematic Geography (2004) adlı çalışmasında benzer biçimde metinsel metaforların hegemonik yapısına itiraz eder, filmlerin birer anlamsal numenleri olmadığını ve doğal olarak bu numenleri anlaşılır kılan bir meta anlatı da sunmayacağını söyler. Filmlerde manzaralar ve diğer ögelerle beraber anlam kurulmaktadır ve bu anlamlar metnin kendi içsel bağlamlarında var olur. Sinemasal mekân kültürel ögeler arasında anlam kazanır ve hatta bakışa maruz kalması açısından kültüre dayalı özgün bir deneyimdir. Diğer bir deyişle, sinemasal coğrafyalar, sadece takip edilen sosyal ve politik olaylarm, ideolojilerin, kimliklerin, inançların ve değerlerin yeniden inşasıyla ilişkili olmayıp aynı zamanda jeopolitik hayali haritalamanın aktif birer katılımcısıdır. Yine derginin aynı sayısında yayinlanan The Rise of Regional Film Production Centers in North America, 1984-1997 adl1 makalesinde Lukinbeal, ekonomik pratiklerin kültürleşmesi ve kültürün dahi bir meta haline gelmesi açısından, kültürel ekonomi ve kültürel endüstrilerin ilişkisinin diyalektik olduğuna dikkat çeker. Dolayısıyla, sinema da bir kültür endüstrisi olarak birçok sembolik anlamın iletişim sürecinde aktarılmasını sağlamaktadır.

Anton Escher Erdkunde'de 2006'da yayınlanmış olan The Georaphy of Cinema adlı çalışmasında, henüz yeni bir çalışma alanı olan sinema coğrafyasının, tartışmaların çerçevesini belirleyecek biçimde -sinemasal konum, sinemasal dünya gibi-, kavramsal karşılıklarını açıklamaktadır. Escher, bu çalışmasında sinemasal coğrafya çalışmalarının ilkelerini belirlemeden hemen önce, klasik coğrafyanın temel aldığı temaların tarihsel bir konsensüs sonucunda belirli metodolojileri ve prosedürleri olduğunu hatırlatır ve beşeri coğrafya araştırmalarının da geleneksel coğrafyanın konularını genişletirken odağının bu belirlenmiş ilke ve yöntemlerinden uzaklaşmaması gerektiğini söyler. Meselenin diğer disiplinleri desteklemek veya filmlerle ilgilenen diğer disiplinlerle arasındaki boşlukları aramaktan ziyade; coğrafi çalışmaların orijinal perspektiflerini, filmlerin sosyal olgularına uygulamak olduğunu söylemektedir. Devamında ise sinemasal coğrafya çalışmalarının dört ilkesini, sinemasal alanların evrimini, işlevlerini, kompozisyonlarını ve bu alanların toplumsal bağlarını ve sonuçlarını gösteren bir kuramın ana hatlarını çizerek, temel çalışma konularını klasik coğrafyanın temel temalarını vurgulayacak şekilde sinemasal manzaranın 
rolünü, işlevini ve inşasını anlaması, sinemasal dünyanın medyadaki kendine referans yaptığı varlığını ve varoluşunu yapı söküme uğratması ve sinemasal tahayyülün mümkün kıldığı mekânlar ile gerçek mekânların arasındaki etkileşimin analiz edilmesi şeklinde belirler.

Stuart C. Aitken ve Deborah P. Dixon, Imagining Geographies of Film (2006) adl1 çalışmalarında Frankfurt Okulu'nun eleştirel yaklaşımını temel alarak sinemasal coğrafyaları, filmin anlatısındaki bir sinematografik öge olarak görürler. Erdkunde'de çıan diğer makalelerle benzer şekilde, sinemasal mekânların anlatının var olduğu ortamı mümkün kılmakla beraber sinemasal anlatının gerçeklikle ilişkilenmesini sağladığını belirtir. Sébastien Caquard ve D. R. Fraser Taylor ise, What is Cinematic Cartography? (2009) adlı çalışmalarında Teresa Castro'ya atıfla, yönetmenin fizikî dünyanın seçilmiş ögelerini çizmesi, kaydetmesi ve arşivlemesi bakımından tıpkı bir kartograf gibi göründüğünü söylemektedirler. Bu bakış açısına göre kamera artık bir sadece kalem değil, aynı zamanda kartografik bir araçtır ve her çeşit coğrafi mekânsal öyküleri (geospatial stories) anlatabilmektedir. Bu son derece ilginç ve yeni bakış açısıyla, daha önce sinemasal coğrafya veya mekân tartışmalarındaki temsiliyet yani betimleme sorunu bir nebze aşılmaktadır. Bu bağlamda sinema tarihinde sürekli auteur olarak görülen yönetmen, artık sadece yazar ya da ressam değil aynı zamanda mekânı yaratan bir kartograftır.

\section{Sonuç: Sinemasal Mekânı Haritalamak}

Bir yönetmen, sinema sanatının kendine özgü olanaklarıla ve bu sanatın kendine özgü anlatısının doğal bir sonucu olarak, zaman ve mekânı yeniden-üretir. Yönetmen, fizikî gerçeklikte varlık bulan mekânlardan, örneğin şehir coğrafyalarından yararlanarak yeni sinemasal mekânlar üretir: "Sinemasal mekânlar fizikî ve/veya deneyimlenmiş mekânların sinema sanatı aracılığıyla dolayımlanarak perdeye ya da ekrana getirilmesiyle vücut bulur. Fizikî mekânlar, sinemasal manzaralar-peyzajlar (cinematic landscapes); sinemasal kent manzaraları (cinematic cityscapes); sinemasal deniz manzaraları (cinematic seascapes) ve benzeri biçimde çerçevelenerek ve kurgulanarak sinemasal mekânlara dönüşür" (Çam, 2016, s. 11). Bu bakımdan yönetmen, çoğu zaman bir yazardan ziyade bir haritacı (kartograf) gibi çalışır ve yeni coğrafyalar yaratır. Bununla beraber sinemasal kent manzaralarının ve şehir coğrafyalarının üretilmesine kaynak sağlaması bakımından -her ne kadar sinema anlatısının içinde biçim değiştirse ve yeni coğrafyalara dönüşse de-, fizikî dünyada varlık bulan şehirler, kültürel coğrafyanın veya daha özelde sinema coğrafyasının önemli bir alanı haline gelmektedir. Bu yüzden sinemasal coğrafyaları araştırmak bize kültürel ve fizikî coğrafya araştırmalarının sağladığından çok daha fazla veri sağlayabilir. Çünkü sinemasal mekânlar, fizikî mekânlarla kıyaslanamayacak biçimde zengin bir içerikle yapılandırılmıştır. Açık ya da örtük biçimde fizikî dünyaya dair ekonomik, kültürel, politik ya da toplumsal veriye sinemasal mekânlar aracılığıyla erişebiliriz. Bu çerçeve etrafında sinema ve mekân, sinemasal coğrafya ve sinemasal kartografya gibi konuların literatür çalışmaları ve onları meşru kılan kavramlar ortaya kondu. Bu araştırma alanları, salt filmin özüne bakmaktan ziyade, filmin ontolojisiyle ve dolayısıyla beşeri coğrafya alanıyla ilişkilendirilerek, sinema çalışmalarını metropollerden çıkarıp hayatın sirayet ettiği ve dolayısıyla sinemasal anlatıya zemin olan diğer coğrafyalarla, kentlerle ilişkilendirme imkânı sağlamaktadır. Bu bağlamda sinema tarihinde sürekli auteur olarak görülen yönetmen, artık sadece yazar ya da ressam değil aynı 
zamanda mekânı yaratan bir kartograftır. Bunu iki açıdan değerlendirebiliriz: İlk olarak hâlihazırda diğer sanat biçimlerini içinde barındıran sinemanın, mekânı bozması ve yeniden yapılandırması, dolayısıyla mimariye sirayet eden bir sanatsal yaratımla da anlam kazanmasıdır. Diğeriyse, sinematografik araçların bir yazarın kaleminden ziyade haritacının malzemesi olduğu düşünüldüğünde, edebiyatın hâlâ okuyucunun hayal gücüne biraktığ1 görsel tahayyül gücünün yönetmenin manipülasyonu altında olmasıdır. Bu durumda Peter Wollen'in Signs and Meaning in the Cinema (1969) ve Andrew Sarris Auteurism is Alive and Well (1974) çalışmalarında açımladıkları auteur kuramlarının ilkeleriyle çatışmadığı gibi yönetmen odaklı bu yaklaşımların, odak noktası olan yönetmenin yaratıcı gücünü arttırır nitelikte olacaktır.

\section{Kaynakça}

Aitken, S. C. \& Dixon, D. P. (2006). Imagining geographies of film. Erdkunde, 60(4), 326- 336.

Aitken, S. C. \& Zonn, L. E. (1994b). Re-presenting the place pastiche. Aitken, S. C. \& Zonn, L. E. (Ed.). In place, power, situation, and spectacle: A geography of film (3-25). Maryland \& Londra: Rowman and Littlefield Publishers, Inc.

Aydın, Hakan. (2008). “Sinemanın Taşrada Gelişim Süreci: Konya'da İlk Sinemalar ve Gösterilen Filmler (1910-1950)". Selçuk Üniversitesi Sosyal Bilimler Enstitüsü Dergisi, 19, 61-74.

Barthes, R. (1979). Göstergebilim ilkeleri. B. Vardar \& M. Rifat (çev.). Ankara: Kültür Bakanlı̆̆1 Yayınları.

Bordwell, D. \& Thompson, K. (2011). Film sanatı - Bir giriş. E. S. Onat \& E. Y1lmaz (çev.), Ankara: De Ki Basım Yayım.

Barthes, R. (1979). Göstergebilim ilkeleri. B. Vardar \& M. Rifat (çev.). Ankara: Kültür Bakanlığ1 Yayınları.

Biltereyst, Daniël. \& Philippe Meers. (2016). New Cinema History and the Comparative Mode: Reflections on Comparing Historical Cinema Cultures. Alphaville: Journal of Film and Screen Media, 11, 13-32.

Biltereyst, Daniël, Richard Maltby \& Philippe Meers. (Eds.) (2019). The Routledge Companion to New Cinema History. New York: Routledge

Bordwell, D. \& Thompson, K. (2011). Film sanatı - Bir giriş. E. S. Onat \& E. Yılmaz (çev.), Ankara: De Ki Basım Yayım.

Bunnuel, T. (2004). Re-viewing the entrapment controversy: megaprojection, (mis)representation and postcolonial performance. Geojpurnal, 59(4), 297-305.

Clarke, D. B. (Ed.). (1997). The Cinematic City. Londra \& New York: Routledge. 
Çam, A. (2016). Derviş Zaim: Bir mekân sineması'na doğru (Doktora tezi). İstanbul: Galatasaray Üniversitesi Sosyal Bilimler Enstitüsü.

Çam, A. (2016). Sinemasal mekânlar ve sinemasal mekânların çözümlenmesi. Sinecine, 7(2), 7- 37 .

Çam, A. (2018). 1960-1975 Yılları arasında Adana'da filmcilik ve sinemacılık işi. Galatasaray Üniversitesi İleti-ş-im Dergisi, 28, 9-41.

Çam, A. (2018). Sinemasal hodolojik mekânlar - Bir zamanlar Anadolu'da filminin hodolojik mekân bağlammnda çözümlenmesi. Ege Üniversitesi İletişim Fakültesi Yeni Düşünceler Hakemli E-Dergisi, 9, 45-56.

Çam, A. \& Şanlıer Yüksel, İ. (2019). Sinema çerçileri - Toros Dă̆ları'nda sinema deneyimi. SineFilozofi Dergisi, Özel Sayı, 415-436.

Escher, A. (2006). The geography of cinema - A cinematic world. Erdkunde, 60(4), 307-314.

Heidegger, M. (1971). Building Dwelling Thinking. Poetry, Language, Thought. Harper Colophan Books, New York.

Heidegger, M. (2013). Being and time. United States: Stellar Books.

Jameson, F. (1992). The geopolitical aesthetic - Cinema and space in the world system. Londra: BFI Publishing.

Kant, I. (1929). Prolegomena to any further metaphysics. Chicago: Open Court Publications.

Kant, I., \& Smith, N. K. (1958). Critique of pure reason. New York: Modern Library Random House.

Kennedy, C. \& Lukinbeal, C. (1997). Towards a holistic approach to geographic research on film. Progress in Human Geography, 21(1), 33-50.

Kırel, S. (2010). Kültürel çalışmalar ve sinema. İstanbul: Kırmızı Kedi Yayınevi.

Liman, Ali Sait. (2014). “Gaziantep'te Sinema, Seyir ve Seyirci (1923-1980)”. İstanbul Üniversitesi İletişim Fakültesi Dergisi, 47, 97-123.

Lukinbeal, C. (1998). Reel -to- real urban geographies: The top five cinematic cities in North America. California Geographer, 38(1), 65-77.

Lukinbeal, C. (2004). The map that precedes the territory: An introduction to essays in cinematic geography. GeoJournal, 59(4), 247-251.

Lukinbeal, C. (2004). The Rise of Regional Film Production Centers in North America, 1984 1997. GeoJournal, 59(4), 307-321. 
Lukinbeal, C. (2005). Cinematic landscapes. Journal of Cultural Geography, 23 (1), 3-22.

Lukinbeal, C. \& Zimmerman, S. (2006). Film geography: A new subfield. Erdkunde, 60(4), 315-325.

Lukinbeal, C., \& Zimmermann, S. (2008). The geography of cinema: A cinematic world. Stuttgart: Steiner.

Maltby, Richard, Daniël Biltereyst, \& Philippe Meers (Eds). (2011). Explorations in new cinema history: approaches and case studies. Chichester, UK: Wiley-Blackwell.

Öztürk, M. (2005). Sine-masal kentler - Modernitenin iki "kahraman"ı kent ve sinema üzerine bir inceleme. İstanbul: Donkişot Yayınları.

Öztürk, M. (Ed.) (2008). Sinematografik kentler: Mekânlar, hatıralar, arzular. İstanbul: Agora Yayınları.

Ryan, M. \& Lenos, M. (2012). Film çözümlemesine giriş - Anlatı sinemasında teknik ve anlam. E. S. Onat (çev.), Ankara: De Ki Yayınları.

Sarris, A. (1974). Auteurism is alive and well. Film Quarterly, 17(4), 60-63.

Şanlıer Yüksel, İ. \& Çam, A. (2019). Çukurova'da 1960-1980 Dönemi Sinema Pratiklerinin Özel Bir Örneği: Yörük Filmleri. Sinecine, 10(2), 291-320.

Uçar İlbuğa, Emine. (2017). “1960-1970’li Yıllarda Kent ve Taşra Karşıtlığında Türkiye'de Kadınların Sinema İzleme Pratikleri Üzerine Bir Araştırma". İletişim Kuram ve Araştırma Dergisi, 45, 388-402.

Wirth, E. (1952). Stoffprobleme des Films. Diss. Freiburg.

Wollen, P. (1969). Signs and meaning in the cinema. Bloomington, Indiana: Indiana University Press. 